\title{
High khat dose and long-term exposure impairs spermatogenesis: experimental study using rabbit model
}

\author{
NYONGESA, A. W. ${ }^{1 *}$, PATEL, N. ${ }^{2}$, WANGO, E. O. ${ }^{1}$ and ONYANGO, D. W. ${ }^{1}$ \\ ${ }^{1}$ Department of Veterinary Anatomy and Physiology, University of Nairobi, P.O Box 30197-00100, Nairobi, Kenya \\ ${ }^{2}$ Department of Medical Physiology, University of Nairobi, P.O Box 30197-00100, Nairobi, Kenya \\ *E-mail: albertnyongesa2011@gmail.com; a.nyongesa@uonbi.ac.ke
}

\begin{abstract}
Introduction: This study investigated short- and long-term effects of khat (Catha edulis) on hypophyseal, epididymal and testicular morphology, body weight and temperature changes and haematological parameters of rabbits. Materials and Methods: Twenty five male New Zealand White rabbits, divided into five groups were used. First four groups were administered, via intra-gastric tube, $1.5,4.5,13.5$ and $40.5 \mathrm{~g} / \mathrm{kg}$ body weight respectively of khat extract thrice a week for 8 weeks while controls received normal saline. Short-term and long-term effects were evaluated for hypophyseal, epididymal and testicular morphology, body temperature as well as body weight changes, food consumption and haematological parameters. Data on haematological parameters, body weight changes, body temperature and food consumption was done using one-way ANOVA at 95\% confidence interval using SPSS version 12.0. Results: There was vacuolation in spermatogonia and spermatocytes at high doses while epididymides and hypophyses were unaffected. A significant decrease $(\mathrm{P}<0.05)$ in body weight of treatment groups correlated with reduced food intake with increasing doses and chronicity of exposure. Packed cell volume, red blood cell count and haemoglobin concentration decreased while white blood cell count increased with increasing doses. Conclusion: Khat extract had direct effects on spermatogenesis compounded by poor body weight gain, hyperthermia and blood volume loss.
\end{abstract}

Keywords: khat, morphology, rabbits, spermatogenesis, testes, histopathology.

\section{Introduction}

Khat is a shrub that either grows wild or is cultivated by inhabitants in the south-west part of Arabian Peninsula and in East African countries and its use confined primarily to areas where it is grown. Its consumption had, nonetheless, spread to most other areas of Asia, Europe, Australia, Canada and United States due to efficient road, water and air transport (COX and RAMPES, 2003) but recently it was banned in the United Kingdom and The Netherlands. Khat and cathinone are also banned substances in the United States (KLEIN, METAAL and JELSMA, 2012). Fresh young leaves and shoots are chewed for their psychoactive properties (FEYISSA and KELLY, 2008). In Kenya, khat is called miraa and it comprises of several varieties among them ghiza, kangeta, makata, matangoma, ngoba, gathanga and kathelwa (CARRIER, 2006). The potency of psycho-activity of the plant varies with variety and freshness of the leaves. The principal ingredient of khat is cathinone that affects the central nervous system like d-amphetamine (ZELGER, SCHORNO and CARLIN, 1980). The psychoactive effects include boosting stamina, preclusion of sleep and several other effects associated with respiratory, digestive and reproductive functions (for review see NYONGESA and ONYANGO, 2010).

Khat chewing has historically been practiced by males among human population, although currently even women have embraced the habit. Data on human and experimental animals show conflicting effects of khat on male reproductive function more specifically with hormonal profiles and gonadal morphological picture. Earlier studies showed that cathinone causes a significant increase in abnormal sperm cells in mice (QURESHI, TARIQ and PAMAR, 1988), rats (ISLAM, TARIQ, AGEEL et al., 1990) and humans (EL-SHOURA, ABDEL AZIZ, ALI et al., 1995). Studies on mutagenicity of khat on germ cells in albino mice showed a reduced rate of fertility in males and post-implantation loss in females during the first week following treatment (TARIQ, QURESHI, AGEEL et al., 1990). In contrast, rabbits fed on freeze-dried leaves of khat had an increased rate of spermatogenesis (AL-MAMARY, AL-HABORI, AL-AGHBARI et al., 2002). The latter report agrees favourably with results on olive baboons that showed an increase in plasma testosterone and a decrease in plasma prolactin and cortisol following khat exposure (MWENDA, OWUOR, KYAMA et al., 2006). The controversies surrounding these findings seem to leave room for more dilemma than provide a reliable trend on the true picture of khat use and reproduction. More detailed and systematic approach in quantification of khat effects on testicular function compounded with effects on other factors that may influence spermatogenesis is scarce. It is also not clear whether anorexic effects of khat as reported by Murray, Le Roux, Emmanuel et al. (2008) correlate with body weight performance thereby influencing reproductive performance. In the present study, we hypothesized that heavy and long-term use of khat causes hyperthermia and loss of appetite that interferes with body weight gain as well as haematological parameters thereby causing histo-pathological changes along pituitary-testicular axis. For testicular morphology, we analysed the effects of khat extract at short- and long-term 
dosing on specific stages of spermatogenesis. Earlier studies on testicular toxicity reported cell-specific effects restricted to specific stages of spermatogenic cycle based on dose and chronicity of exposure (ANDERSON, BRINKWORTH, JENKINSON et al., 1987). The New Zealand white rabbit was chosen as an experimental animal since it is easy to handle, less expensive and its reproductive processes are well documented (AMANN, 1982; SWIERSTRA and FOOTE, 1963).

\section{Materials and Methods}

\subsection{Animals and housing}

Twenty-five sexually mature New Zealand White male rabbits, aged between 9 and 12 months and weighing 2 to $3 \mathrm{~kg}$, were obtained from a breeding colony at the School of Biological Sciences, University of Nairobi, Kenya. The animals were fed on standard rabbit pellets (Unga Feeds, Kenya), green vegetables, carrots and commercial vitamins and water supplied ad libitum. Lighting conditions of approximately $12 \mathrm{~h}$ light: $12 \mathrm{~h}$ dark cycle and an average room temperature of $23^{\circ} \mathrm{C}$ with a humidity of approximately $60 \%$ were provided in animal house. Each rabbit was housed in single cages $(40.5 \mathrm{~cm} \times 40.5 \mathrm{~cm} \times 61 \mathrm{~cm})$ placed on a raised surface. All protocols for animal experimentation of this study were approved by Animal Care and Use Committee of the University of Nairobi.

\subsection{Preparation of crude khat extract}

Fresh leaves and shoots of khat were obtained from Nyambene, Meru district of Kenya. Four doses $(1.5,4.5,13.5$ and $40.5 \mathrm{~g} / \mathrm{kg}$ body weight) were prepared by first formulating a working concentration of $20 \mathrm{~g} / \mathrm{ml}$ by blending and dissolving $200 \mathrm{~g}$ of leaves in $10 \mathrm{ml}$ of normal saline. For a rabbit weighing $2 \mathrm{~kg}$ and requiring a dose of $1.5 \mathrm{~g} / \mathrm{kg}, 0.15 \mathrm{ml}$ was drawn from working concentration and constituted to a final volume of $5 \mathrm{ml}$ with normal saline. For $4.5 \mathrm{~g} / \mathrm{kg}, 0.45 \mathrm{ml}$ was drawn, $1.35 \mathrm{ml}$ for $13.5 \mathrm{~g} / \mathrm{kg}$ while $4.05 \mathrm{ml}$ for $40.5 \mathrm{~g} / \mathrm{kg}$ were drawn from same working concentration constituted to a final volume of $5 \mathrm{ml}$.

\subsection{Experimental design}

The animals were randomly assigned five groups each comprising five animals and habituated to handling and insertion of intra-gastric tube for about $20 \mathrm{~min}$ daily for 14 days before commencement of experiments. Group I animals served as controls and each was given $5 \mathrm{ml}$ normal saline via intra-gastric tube three times a week (Mondays, Wednesdays and Fridays at $09.00 \mathrm{~h}$ ) for 8 weeks. Animals in groups II to $\mathrm{V}$ were given $1.5,4.5,13.5$ and $40.5 \mathrm{~g} / \mathrm{kg}$ body weight of khat extract in $5 \mathrm{ml}$ volume respectively, via an intra-gastric tube following same regimen as for controls. The choice of these doses was guided by an average amount of $4.5 \mathrm{~g} / \mathrm{kg}$ body weight a regular khat chewer consumes per day as earlier reported (FEYISSA and KELLY, 2008). This study explored effects of khat on functional systems in a situation of misuse and over a substantial period. Since the study was designed to test dose-response effects, we chose to use a lower dose through to doses above daily average consumption and over an elongated period of exposure.

\subsection{Clinical assessment}

Body weight of each rabbit was measured using a weighing balance (MRC Model: BWL C-6-A2) each day prior to and after administration of crude khat extract and recorded over the period of the experiment. Body weight gain/loss (g) was determined by subtracting the body weight of rabbits at the start of the experiment from any additional or reduction in body weight for different khat doses over the experimental period. Food intake $(\mathrm{g})$ in both test and control animals were monitored daily by subtracting the weight of food remaining from weight of food given to the animal the previous day. Feeding and water troughs were anchored on the wire mesh of the cage at a raised surface to avoid spillage.

\subsection{Blood sampling for haematology}

Blood collection commenced 10 min after khat administration and $0.5 \mathrm{ml}$ samples were collected using needle $(22 \mathrm{G})$ and syringe into heparinized $\mathrm{LP}_{3}$ tubes containing heparin and gently mixed to avoid clotting. Non-heparinised capillary tubes were filled three-quarter with heparinised blood sample. The tubes were then exposed to non-luminous flame to expel air inside, tips sealed and placed in wells of micro-haematocrit centrifuge with sealed tips facing centripetally and spun at $1500 \mathrm{xg}$ for $5 \mathrm{~min}$. The length of the column of packed cells and that of packed cells plus plasma was measured and the ratio calculated as a percentage to determine Packed Cell Volume (PCV). Haemoglobin concentration was measured using the acid haematin method where 0.1 N HCL was pipetted up to $20 \%$ mark of the haemoglobin graduated tube and $20 \mu \mathrm{l}$ of heparinised blood sample added and mixed vigorously using a mixing rod. Acid haematin formed after about 3 min when haemoglobin reacted with HCL. By use of a Pasteur pipette, distilled water was added drop by drop to the haemoglobin tube in the haemoglobinometer and stirred each time using a mixing rod until the colour of the solution matched that of the haemoglobinometer. This gave the amount of haemoglobin in $\mathrm{g} / \mathrm{l}$.

Red blood cell (RBC) and white blood cell counts (WBC) were done with a haemocytometer. For RBC, Hayem's solution (containing $0.9 \%$ sodium chloride [Riedel-de Haën AG]) was used while for WBC, the dilution fluid ( $2 \%$ glycerol acetate and Gentian Violet) was used. For the case of RBC the 4 peripheral smaller squares and 1 central smaller square in the central big square of the haemocytometer were used and the number multiplied by a factor of 10,000 . For the WBC, the cells in the four peripheral and central big squares of the haemocytometer were counted and multiplied by a factor of 40 .

\subsection{Histopathological examination}

The hypophyses, testes and epididymides of two animals from each of the four treatment groups were harvested following 14 days of khat extract treatment for short-term effects, while the remaining animals were sacrificed 56 days later to study long-term effects. Animals were euthanised with diethyl ether (Eastman Chemical Co., Tennessee, USA) and fixed by intra-cardiac perfusion using $2.5 \%$ phosphate buffered glutaraldehyde ( $\mathrm{pH} 7.4$ ). The testes, epidydimides and hypophyses were then harvested, immersed in the same fixative for 7 days and trimmed into sufficiently small sizes $\left(1 \mathrm{~mm}^{3}\right)$ to permit proper fixation and processing. Thereafter, tissue blocks were post-fixed in $4 \% \mathrm{w} / \mathrm{v}$ osmium tetroxide for $2 \mathrm{~h}$, dehydrated through ascending concentrations of ethanol $(20,40,50,60,70,80,90$, and absolute alcohol $)$, cleared using propylene oxide and infiltrated with epoxy-resin mixture. Sections ( $1 \mu \mathrm{m}$ thick) were then obtained from the tissue blocks using a Sorvall ${ }^{\circledR}$ ultra microtome, mounted on moistened glass 
slides, fixed and stained with toluidine blue. Photographs were taken using Zeiss Axioscop Camera (Carl Zeiss, Germany).

\subsection{Statistical analysis}

Data analysis was performed using the Statistical Packages for Social Sciences for Windows Version 12.0 (SPSS Inc., IL). Data is expressed as mean \pm SEM. For body weight changes, daily food intake, body temperature and haematological parameters of PCV, haemoglobin concentration and whole blood cell count, comparison of means among treatment groups and controls was performed using one-way ANOVA followed by Tukey's multiple comparison post hoc tests. Significance level was set at $5 \%$.

\section{Results}

\subsection{Effects of khat extract on testicular, epididymal and adenobypophyseal morphology}

\subsubsection{Testes}

The focus on testicular morphology in present study was on effects of khat extract on seminiferous epithelium at different stages of development as well as interstitial cells of Leydig for possible effects on androgen production. The study on rabbit spermatogenic cycle was guided by an earlier classification into eight stages based on location of spermatids and spermatozoa in relation to basement membrane, presence of meiotic figures and release of spermatozoa into
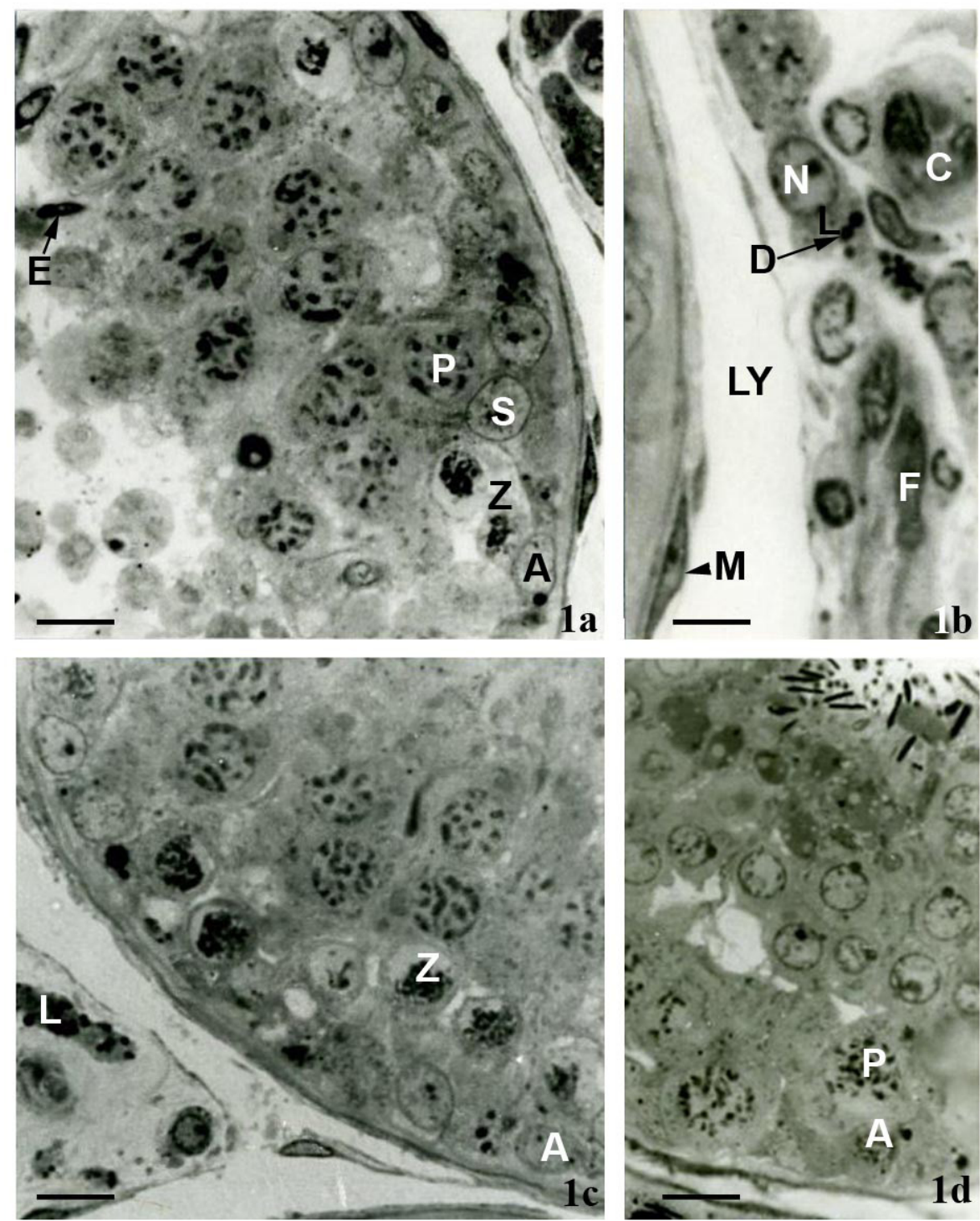

Figure 1. 1a) Normal morphology of the seminiferous tubule at stage 2 of spermatogenic cycle of control rabbits after 8 weeks of saline treatment showing Sertoli cells (S), type A spermatogonia (A), zygotene spermatocytes (Z), pachytene spermatocytes (P) and elongate spermatids $(\mathrm{E}) . \mathrm{Bar}=10$ micron. Toluidine Stain; $\mathrm{lb}$ ) Interstitial tissue of control rabbits after 8 weeks of the experiment showing Leydig cells (L) with marginations of heterochromatin in the nucleus (N) and lipid droplets (D). Lymphatic vessel (LY), peritubular myoid cells $(\mathrm{M})$, blood capillaries $(\mathrm{C})$ and fibroblasts $(\mathrm{F})$ are present. lc) Note the similarity of type A spermatogonia (A) and zygotene spermatocytes (Z) with those of the controls. Similarly, Leydig cells (L) appear unaffected by khat treatment. $\mathrm{Bar}=10$ micron. Toluidine Stain; ld) Seminiferous epithelium at stage 7 of spermatogenic cycle at 8 weeks after $1.5 \mathrm{~g} / \mathrm{kg}$ body weight of khat extract treatment. Type A spermatogonia (A) and pachytene spermatocytes (P) appear similar to those of controls. Bar $=10$ micron. Toluidine Stain. 
lumen (SWIERSTRA and FOOTE, 1963). At 14 days of khat treatment, both the seminiferous tubules (Figure la) and interstitium (Figure $1 \mathrm{~b}$ ) of control rabbits showed normal morphology. Germinal epithelium in Figure la was classified as stage 2 of spermatogenic cycle characterized by elongation of spermatid nuclei and two generations of primary spermatocytes with indistinct nuclei membrane. Sertoli cells and type A spermatogonia were observed along the basement membrane.

Testicular morphology of khat- treated animals showed various degrees of degenerative changes in immature germ cells. At the lowest dose of khat extract, the seminiferous tubules at both short-term (Figure lc) and long-term (Figure ld) phases of treatment did not show any appreciable structural changes from controls. Figure lc was classified as stage 1 of spermatogenic cycle characterized by presence of type A spermatogonia and Sertoli cells along the basement membrane. Also present include young (zygotene) and old (pachytene) primary spermatocytes and spermatids with round nuclei and darkly staining acrosome. On the other hand Figure 1d was classified under stage 7 of spermatogenic cycle characterized by presence of Sertoli cells and type A spermatogonia along basement membrane while pachytene spermatocytes showed dense chromatin network with general increase in nuclei size. Spermatid nuclei appeared spherical with clear nuclear membrane and visible acrosome on surface membrane while spermatozoa appeared moving towards the lumen. Within the interstitium, Leydig cells of treatment groups displayed structural characteristics similar to those observed for controls suggesting that Leydig cells were, perhaps, unresponsive to khat extract exposure. In rabbits treated with high (13.5 g/ $\mathrm{kg}$ and $40.5 \mathrm{~g} / \mathrm{kg}$ body weight) doses of khat extract, there were structural changes within seminiferous epithelium at both short- and long-term phases of treatment. In the short-term (Figure $2 \mathrm{a}$ ), at stage 7 of spermatogenic cycle, and long-term (Figure $2 \mathrm{~b}$ ), at stage 1 of spermatogenic cycle, khat treatment with $13.5 \mathrm{~g} / \mathrm{kg}$ body weight, testicular tissue showed round vacuoles of varying sizes in spermatogonia and young primary spermatocytes in their pre-leptotene phase with accompanying degeneration of chromatin material while mature
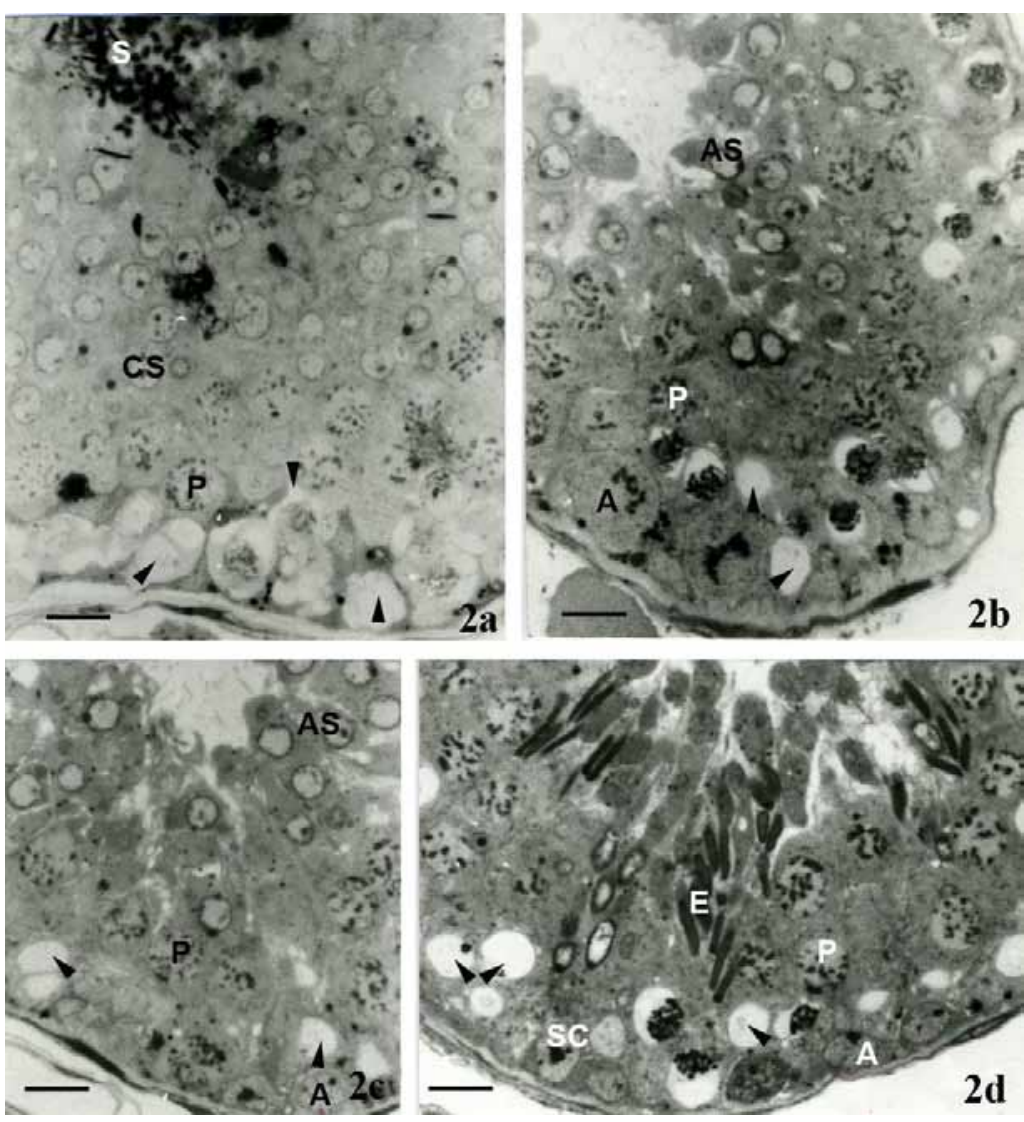

Figure 2. 2a) Seminiferous tubule at stage 7 of spermatogenic cycle 2 weeks after treatment with $13.5 \mathrm{~g} / \mathrm{kg}$ body weight of khat extract showing degeneration and vacuolation in spermatogonia and zygotene spermatocytes (arrows). Pachytene spermatocytes $(\mathrm{P})$ and cap phase spermatids (CS) appear normal. The lumen contains spermatozoa (S). Bar $=10$ micron. Toluidine Stain; 2b) Seminiferous tubule of rabbit testis at stage 1 of spermatogenic cycle at 8 weeks of $13.5 \mathrm{~g} / \mathrm{kg}$ body weight of khat extract treatment. Note similar vacuolations (arrow heads) in zygotene spermatocytes comparable to those of short-term khat exposure (Figure 4a). Pachytene spermatocytes (P) and acrosomal phase spermatids (AS) appear normal. Type A Spermatogonia (A) is also evident. Bar - 10 micron. Toluidine Stain; 2c) Seminiferous tubule of rabbit at stage 1 of spermatogenic cycle treated for 2 weeks with $40.5 \mathrm{~g} / \mathrm{kg}$ body weight of khat extract. Vacuolations (arrow heads) in zygotene spermatocytes is evident. Pachytene spermatocytes (P) and acrosomal phase spermatids (AS) appear normal. Type A spermatogonia (A) are present. Bar = 10 micron. Toluidine Stain; 2d) Seminiferous tubule of rabbit at stage 3 of spermatogenic cycle at 8 weeks of $40.5 \mathrm{~g} / \mathrm{kg}$ body weight of khat extract treatment. Notice enhanced degeneration accompanied by vacuolations (arrow heads) in zygotene spermatocytes. Type A spermatogonia (A), Sertoli cell (SC), Pachytene spermatocytes $(\mathrm{P})$ and elongate spermatids $(\mathrm{E})$ appear normal. Bar $=10$ micron. Toluidine Stain. 
forms of seminiferous tubular germ cells appeared normal. In the short-term phase of high dose of khat extract, there was continued vacuolation and degeneration of spermatogonia and young primary spermatocytes in their pre-leptotene phase as shown at stage 1 of spermatogenic cycle (Figure 2c). These young primary spermatocytes in stage 1 were located near the basement membrane and had round nuclei with faint stained chromatin. Long-term phase showed enhanced degeneration and vacuolation of zygotene spermatocytes (Figure $2 \mathrm{~d}$ ) but pachytene spermatocytes and elongate spermatids appeared normal. The seminiferous epithelium in this slide section was classified as stage 3 of spermatogenic cycle characterized by presence of Sertoli cells and type A spermatogonia lying along the basement membrane. Two generations of primary spermatocytes: zygotene with small nuclei and pachytene with large nuclei and elongate spermatids were also present within the tubules.

\subsubsection{Epididymides and adenohypophysis}

The different doses of khat extract did not have any observable effect on the epididymal and adenohypophyseal morphology. Caput, corpus and cauda epididymal epithelia showed normal morphology (Figure 3a, b and c). The cytoplasm in all cases contained numerous secretory granules, prominent Golgi apparatus and multi-vesicular bodies. Similarly, khat extract at all doses appeared to have no detrimental effect on the adenohypophysis in treatment groups. At all khat doses, the tissue showed gonadotropes that appeared as large rounded less staining cells close to blood capillaries with irregular nuclei while acidophils appeared deeply staining with numerous secretory granules in the cytoplasm (Figure $3 \mathrm{~d}$ ).
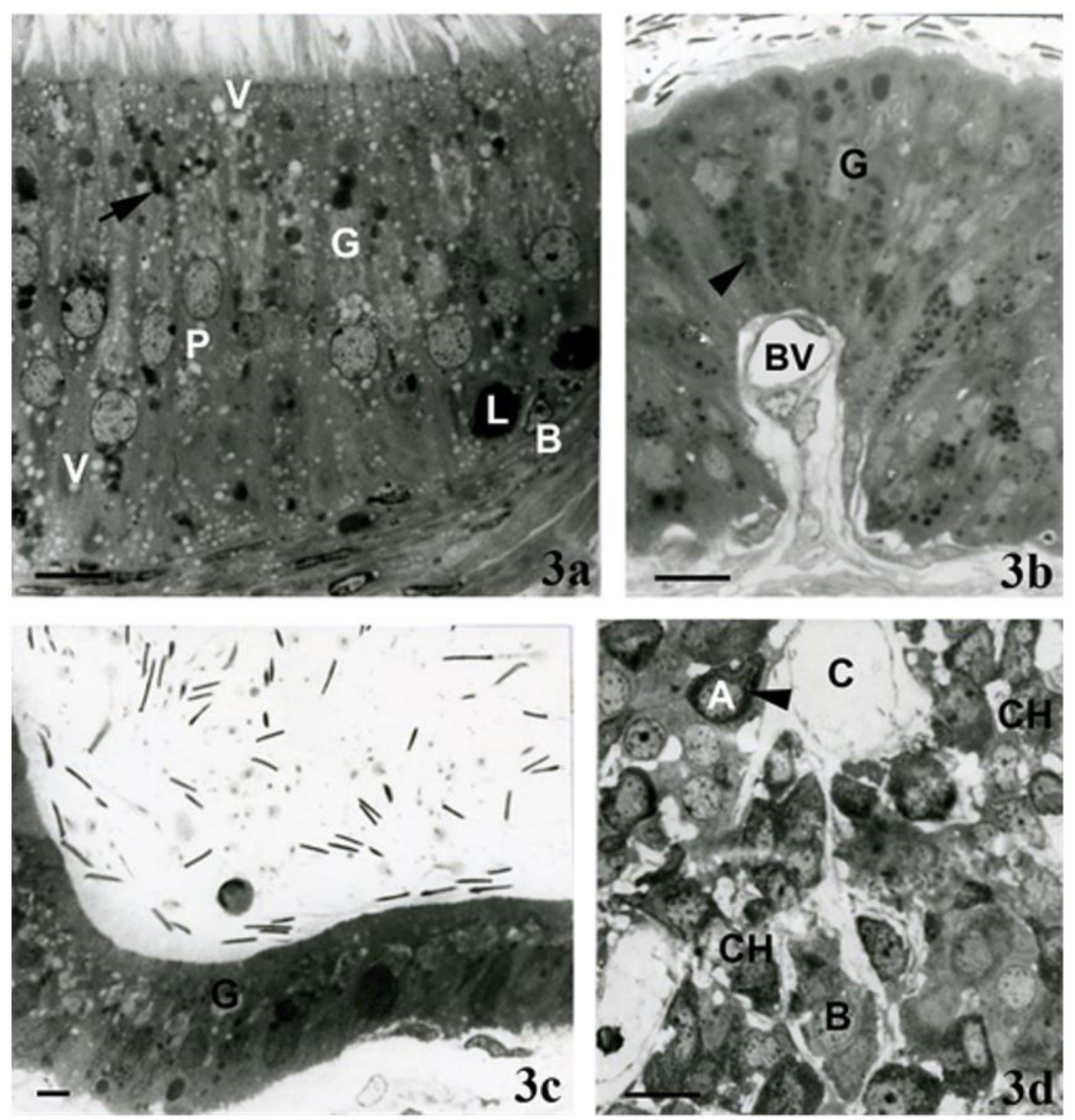

Figure 3. 3a) Caput epididymal epithelium of rabbit treated for 8 weeks with $40.5 \mathrm{~g} / \mathrm{kg}$ body weight of khat extract showing tall principal cells (P). Heterogeneous dense bodies (arrow), apical and basal micropinocytotic vesicles (V) and well developed Golgi apparatus (G) are present. Basal cells (B) and intra-epithelial lymphocytes (L) are scattered between principal cells. Bar $=10$ micron. Toluidine Stain; 3b) Corpus epididymis of khat-treated rabbit for 8 weeks with $40.5 \mathrm{~g} / \mathrm{kg}$ body weight. Secretory granules (arrow head) and Golgi apparatus $(\mathrm{G})$ are present. Bar $=10$ micron. Toluidine Stain; 3c) Cauda epididymal epithelium of rabbit treated for 8 weeks with $40.5 \mathrm{~g} / \mathrm{kg}$ body weight of khat extract generally showing normal morphology. Golgi apparatus (G) are present. Bar $=24 \mathrm{micron}$. Toluidine Stain; 3d) Experimental adenohypophysis showing normal clusters of glandular cells mainly around blood capillaries (C). Basophils (B) with light staining cytoplasm, acidophils (A) with deeply stained cytoplasm and abundant secretory granules (arrow) and chromophobes $(\mathrm{CH})$ with light-staining cytoplasm are present. Bar $=10$ micron. Toluidine Stain. 


\subsubsection{Effect of khat extract on body temperature, body weight and daily food intake}

None of the rabbits showed adverse clinical signs throughout the experimental period. Rectal temperatures were within normal range $\left(38\right.$ to $39.5^{\circ} \mathrm{C}$ ) in saline-treated controls and at low doses ( $1.5 \mathrm{~g} / \mathrm{kg}$ and $4.5 \mathrm{~g} / \mathrm{kg}$ body weight) of khat extract $\left(38.8 \pm 0.02{ }^{\circ} \mathrm{C}\right.$ and $38.9 \pm 0.04{ }^{\circ} \mathrm{C}$ respectively $)$. However, at dose $13.5 \mathrm{~g} / \mathrm{kg}$ and $40.5 \mathrm{~g} / \mathrm{kg}$ body weight there was significant increase $(\mathrm{P}<0.5)$ to $40.3 \pm 0.13^{\circ} \mathrm{C}$ and $41.1 \pm 0.19^{\circ} \mathrm{C}$, respectively (Figure $4 \mathrm{a}$ ) in a dose-related manner (Figure $4 \mathrm{~b}$ ). The mean body weight change among treatment groups was significantly different $(\mathrm{P}<0.05)$ (Figure 5a) compared to controls. Post hoc test with Tukey's multiple comparison showed the change in mean body weight of the saline-treated controls $(1.886 \pm 0.168 \mathrm{~kg})$ being significantly higher $(\mathrm{P}<0.05)$ than the khat extract-treated rabbits at the end of experimental period. The decrease was significant at $13.5 \mathrm{~g} / \mathrm{kg}$ and $40.5 \mathrm{~g} / \mathrm{kg}$ body weight of khat extract (Figure $5 \mathrm{~b}$ ). At all doses of khat extract administration, food consumption by the rabbits was suppressed (Figure 6a) with dose $40.5 \mathrm{~g} / \mathrm{kg}$ body weight showing the highest decline $(51.47 \pm 9.716 \mathrm{~g})$, while $1.5 \mathrm{~g} / \mathrm{kg}$ body weight showing the least drop in food consumption (109.82 $\pm 1.484 \mathrm{~g}$ ) (Figure 6b).

\subsubsection{Effects of khat extracts on haematological parameters}

Red blood cell count, white blood cell count, haemoglobin and packed cell volume showed a significant difference $(\mathrm{P}<0.05)$ between saline-treated controls and treatment groups. Khat extract reduced RBC count at all doses of khat extract (Figure 7a) and the effects were dose-related. The mean RBC count over 8 week experimental period reduced significantly $(\mathrm{P}<0.05)$ with the greatest suppressive effects at highest two doses (13.5 g/ $\mathrm{kg}$ and $40.5 \mathrm{~g} / \mathrm{kg}$ body weight), whereas the least suppression observed at $1.5 \mathrm{~g} / \mathrm{kg}$ body weight (Figure $7 \mathrm{~b}$ ).

Haemoglobin concentration showed a similar trend (Figure 8a) with mean haemoglobin concentration between khat doses being significantly different manifesting a significant reduction over the experimental period $(\mathrm{P}<0.05)$. The highest two khat doses showed the greatest decrease in haemoglobin $(10.86 \pm 0.558 \mathrm{~g} \%$ and $9.998 \pm 0.768 \mathrm{~g} \%$, respectively). The effects of khat extract on haemoglobin were dose-dependent (Figure $8 \mathrm{~b}$ ). There was a significant increase $(\mathrm{P}<0.05)$ in WBC count between treatment groups and over experimental period compared to controls (Figure 9a). There was a dose-related increase in WBC count with the highest dose ( $40.5 \mathrm{~g} / \mathrm{kg}$ body weight $)$ showing significant effect while controls the least effect (Figure 9b). Mean PCV, however, significantly decreased $(\mathrm{P}<0.05)$ with increasing khat dose and over experimental period (Figure 10a). The suppressive effect was dose-related (Figure 10b) reducing from $35.64 \pm 0.087 \%$ in controls to $32.81 \pm 0.80 \%$ at $40.5 \mathrm{~g} / \mathrm{kg}$ body weight.

\section{Discussion}

The present study was designed to investigate the short- and long-term effects of khat extract directly on testicular histology and whether effects on changes in daily food intake, body weight and temperature changes as well as haematological parameters compounded the effects on this measure. The short-term studies were done for 2 weeks while long-term effects lasted 8 weeks. Although it is recommended that for sub-chronic toxicity studies, exposure of treatment should continue for at least 6 cycles ( 64 days) before fertility testing (AMANN,

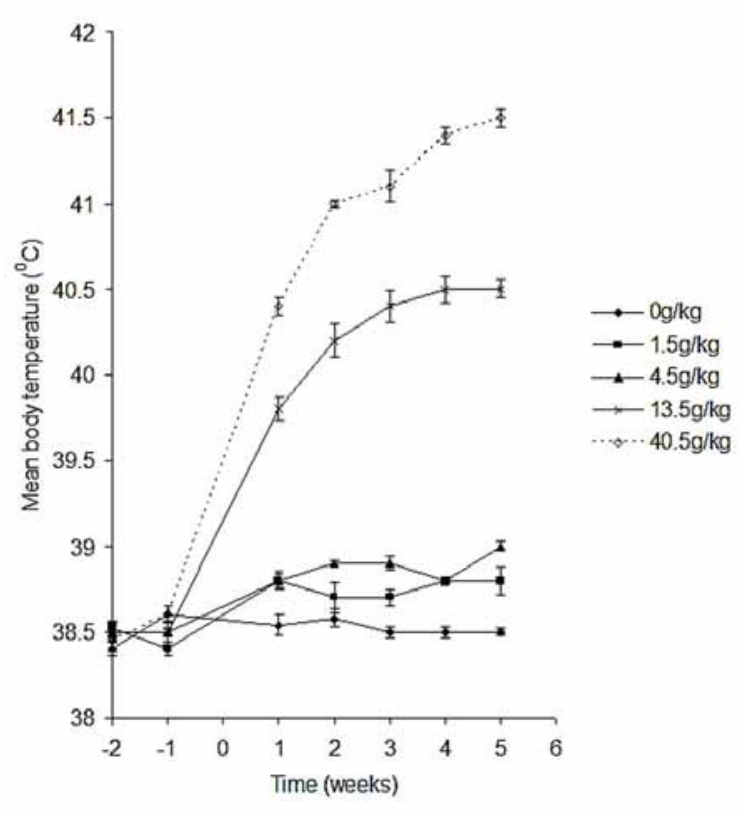

Figure 4a. Effect of khat extract on core body temperature 2 weeks before and 5 weeks after khat treatment. Body temperature measurements in saline-treated controls and khat-treated rabbits were taken after $3 \mathrm{~h}$ of khat administration. Body temperature increased at all dosages with significant increment $(\mathrm{P}<0.05)$ at $13.5 \mathrm{~g} / \mathrm{kg}$ and $40.5 \mathrm{~g} / \mathrm{kg}$ body weight of khat extract as compared to controls. $\mathrm{n}=25$;

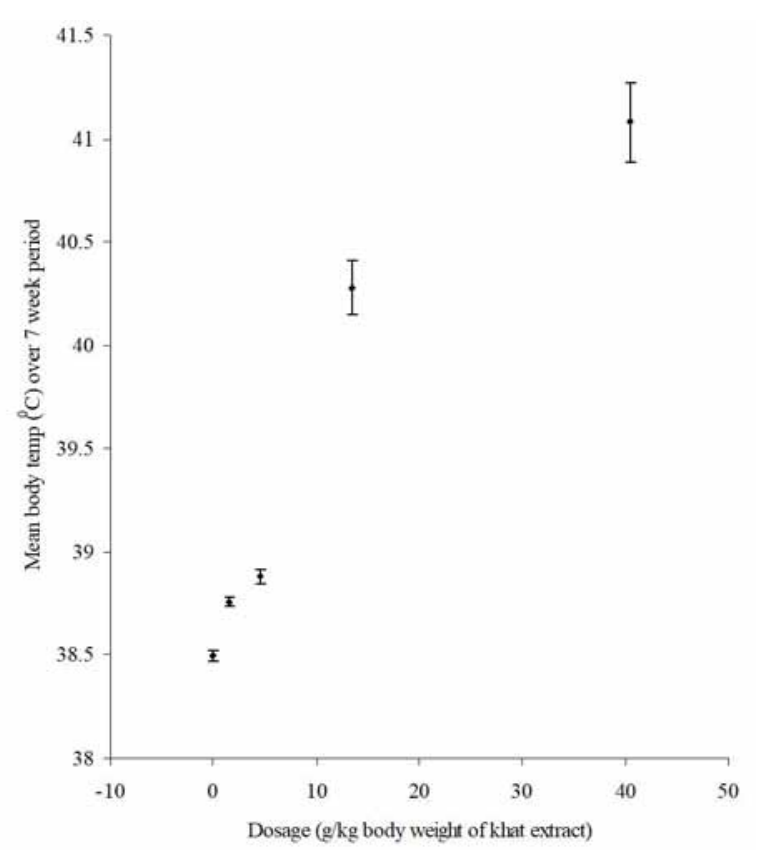

Figure 4 b. Mean body temperature of rabbits 2 weeks before and 5 weeks after khat treatment as a function of khat dose. Khat extract caused a transient increase in body temperature of rabbits at all dosages and which subsided at about $5 \mathrm{~h}$ after khat administration. Significant increase was seen in rabbits treated with $13.5 \mathrm{~g} / \mathrm{kg}$ and $40.5 \mathrm{~g} / \mathrm{kg}$ body weight of khat extract $(\mathrm{P}<0.05)$ compared to controls; $\mathrm{n}=25$. 
1982), the same author reports that it takes 4.5 cycles ( 48 days) for a committed type A spermatogonia to differentiate into spermatozoa in rabbits. It is based on this understanding that the 56- day sub-chronic exposure was chosen. Although the present study does not focus on pesticides and testicular toxicity,

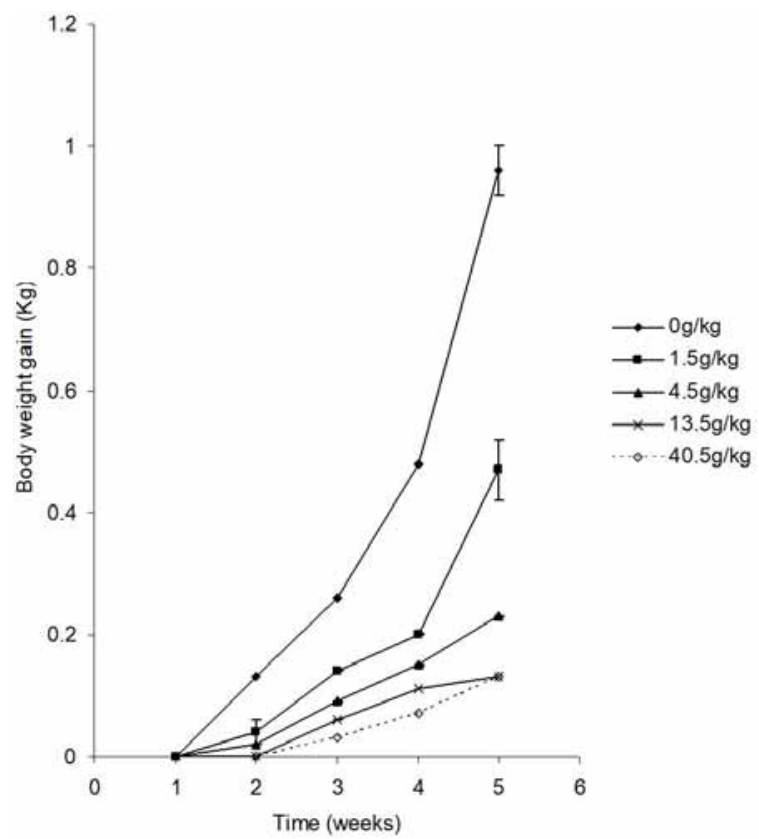

Figure 5a. Effect of khat extract on body weight gain $(\mathrm{kg})$ in saline and khat-treated rabbits over the experimental period. Khat extract suppressed body weight gain over the experimental period with highest effect at week 5 of experiments.

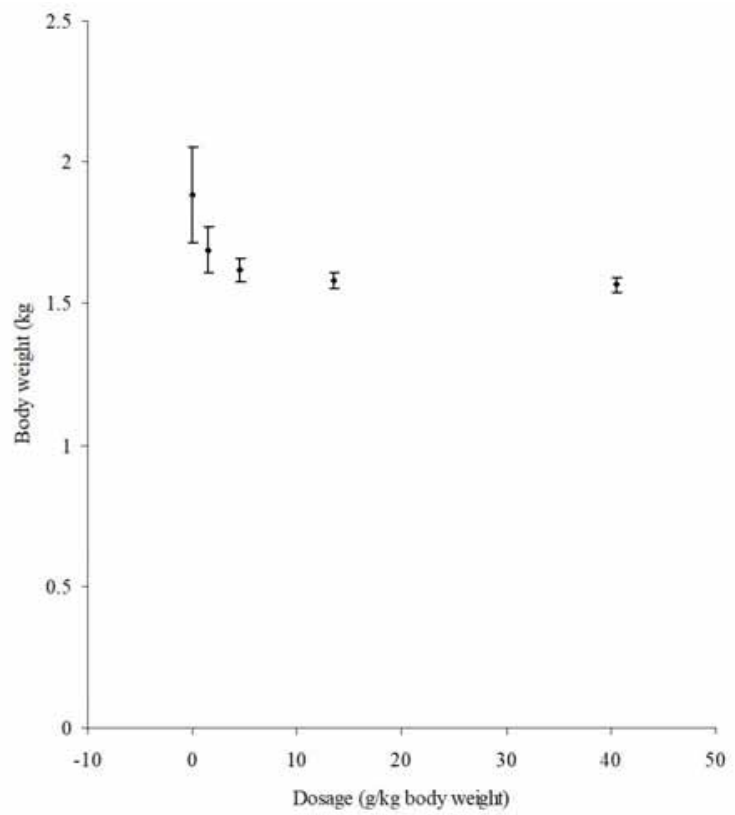

Figure 5b. Body weight gain in controls and khat-treated rabbits as a function of khat dose over the experimental period of 5 weeks. At doses $4.5 \mathrm{~g} / \mathrm{kg}, 13.5 \mathrm{~g} / \mathrm{kg}$ and $40.5 \mathrm{~g} / \mathrm{kg}$ body weight, khat extract caused a significant decrease in body weight gain $(\mathrm{P}<0.05)$ with the highest suppression at dose $40.5 \mathrm{~g} / \mathrm{kg}$ body weight of khat extract as compared to saline-treated controls; $\mathrm{n}=25$ rabbits it considered khat as a potentially toxic substance to germinal epithelium. In the experimental design, we followed Health Effects Test Guidelines for reproductive and developmental toxicity screening tests (ENVIRONMENTAL..., 2000).

The process of spermatogenesis is regulated not only by classical endocrine control of hypothalamic-pituitary-gonadal axis but also by complex interaction involving seminiferous epithelium, Leydig cells, peri-tubular cells, macrophages and endothelial cells of interstitial vasculature. Testicular histology has been shown to be the most sensitive and reliable method of detecting effects

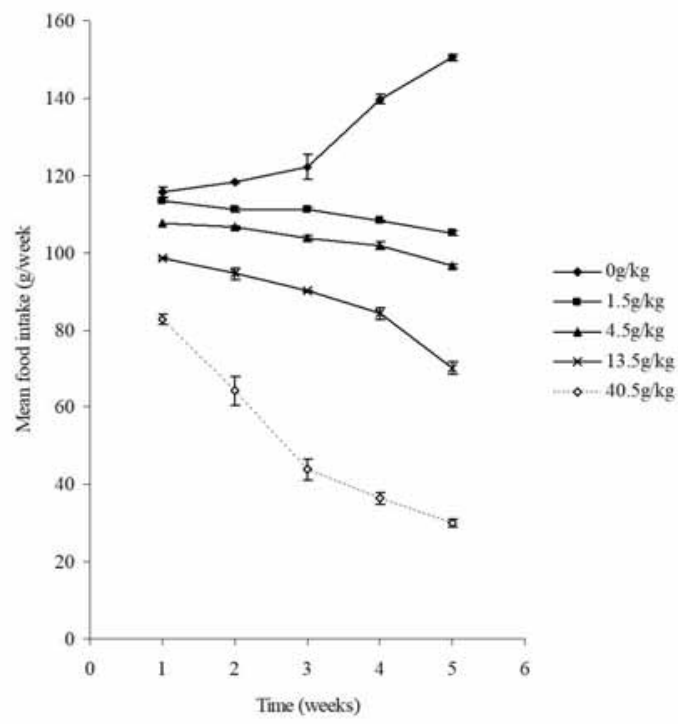

Figure 6a. Effect of khat extract on weekly food consumption in saline and khat-treated rabbits. Food intake was significantly reduced $(\mathrm{P}<0.05)$ at all doses of khat extract as compared to controls. The highest dose of $40.5 \mathrm{~g} / \mathrm{kg}$ body weight of khat extract showed the highest suppression of food intake. $n=25$.

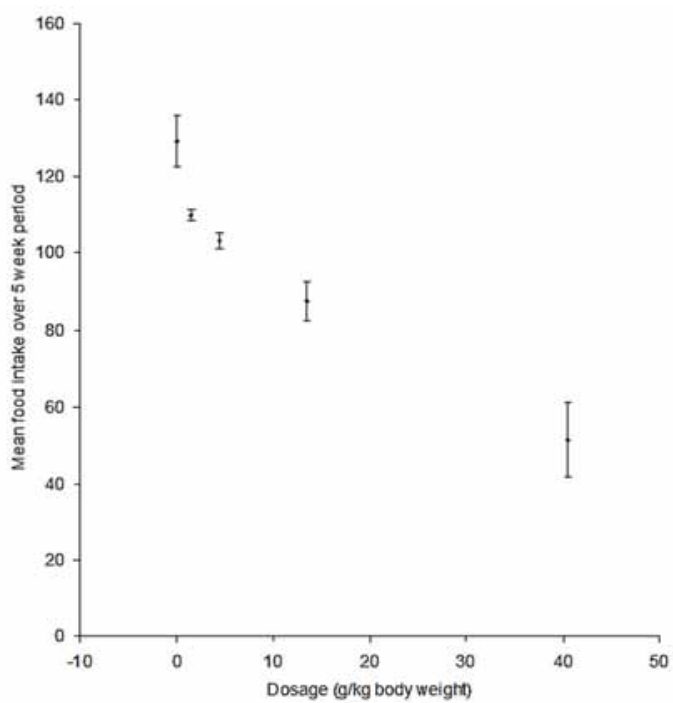

Figure 6b. Food consumption in both controls and khat-treated rabbits as a function of khat dose. Khat extract significantly suppressed $(\mathrm{P}<0.05)$ food intake in khat-treated rabbits, with the highest effect at $40.5 \mathrm{~g} / \mathrm{kg}$ body weight of khat extract as compared to controls. $\mathrm{n}=25$. 


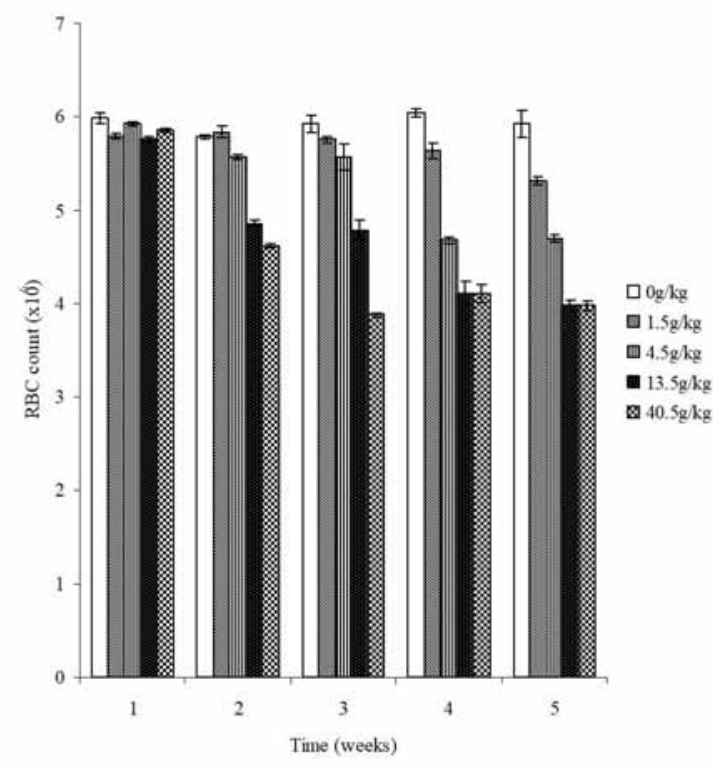

Figure 7a. Mean Red Blood Cell (RBC) count in saline and khattreated rabbits over experimental period. RBC count decreased significantly $(\mathrm{P}<0.05)$ at all doses in a time-related manner. $\mathrm{n}=25$.

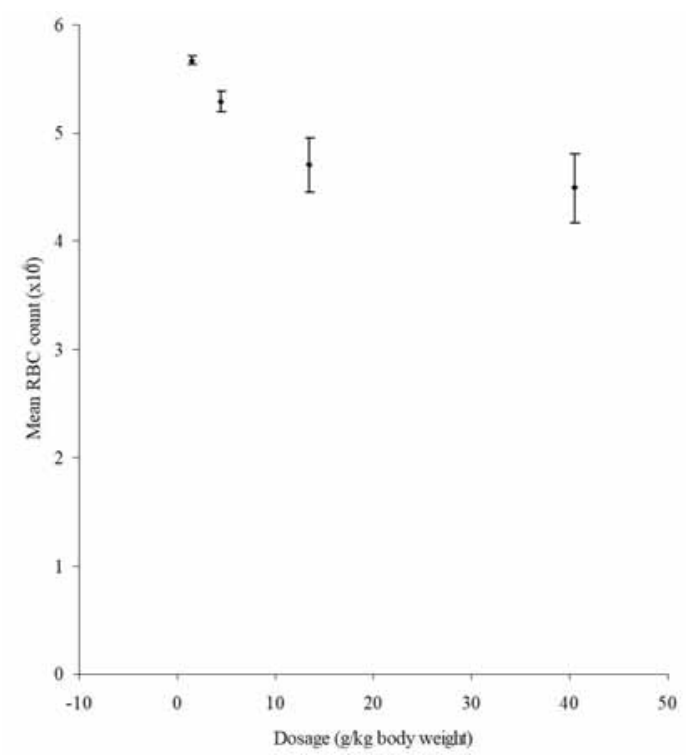

Figure $7 \mathbf{b}$. Mean Red blood cell count in saline and khat-treated rabbits as a function of khat dose. Khat extract suppressed RBC count in a dose-related manner, with $40.5 \mathrm{~g} / \mathrm{kg}$ body weight of khat extract causing the highest effect $(\mathrm{P}<0.05)$ compared to controls. The decrease in the highest dose, however, was within the physiological limit. $\mathrm{n}=25$.

of toxic agents on spermatogenesis (TAKAYAMA, AKAIKE, KAWASHIMA et al., 1995). Sperm count is not a very accurate and reliable tool since it results in significant variation among individuals and over sampling periods in the same individual (CREASY, 1997). Many toxic agents have been shown to have cell-specific effects restricted to specific stages of the spermatogenic cycle depending on dose and duration of exposure (ANDERSON, BRINKWORTH, JENKINSON et al., 1987). To this end, the present study investigated short-and long-term

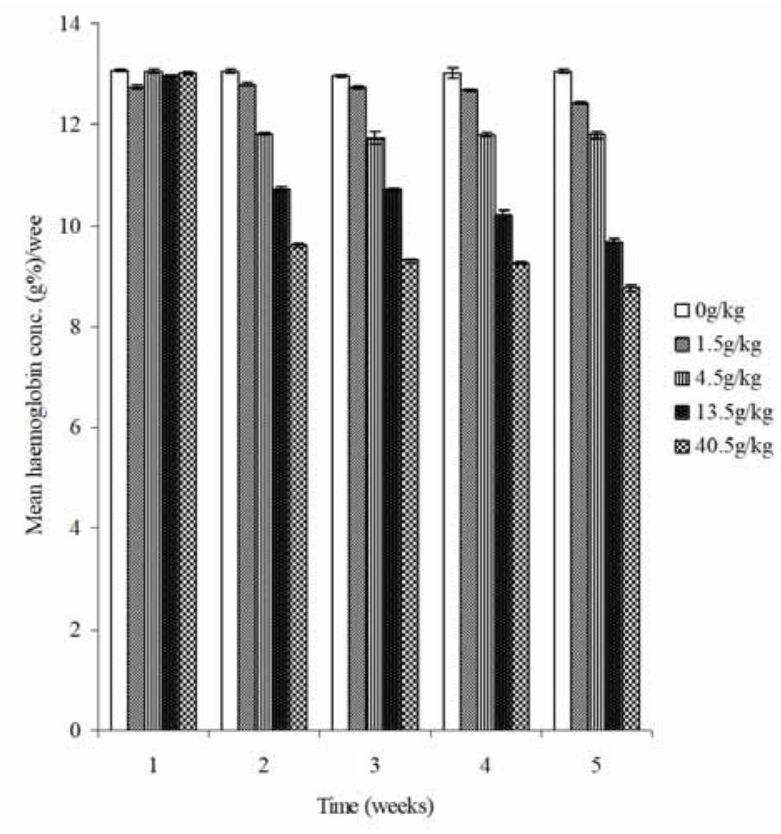

Figure 8a. Mean haemoglobin $(\mathrm{Hb})$ concentration in saline and khat-treated rabbits over experimental period. Haemoglobin concentration showed a significant decrease in khat-treated rabbits over time $(\mathrm{P}<0.05 ; \mathrm{n}=25$ rabbits $)$.

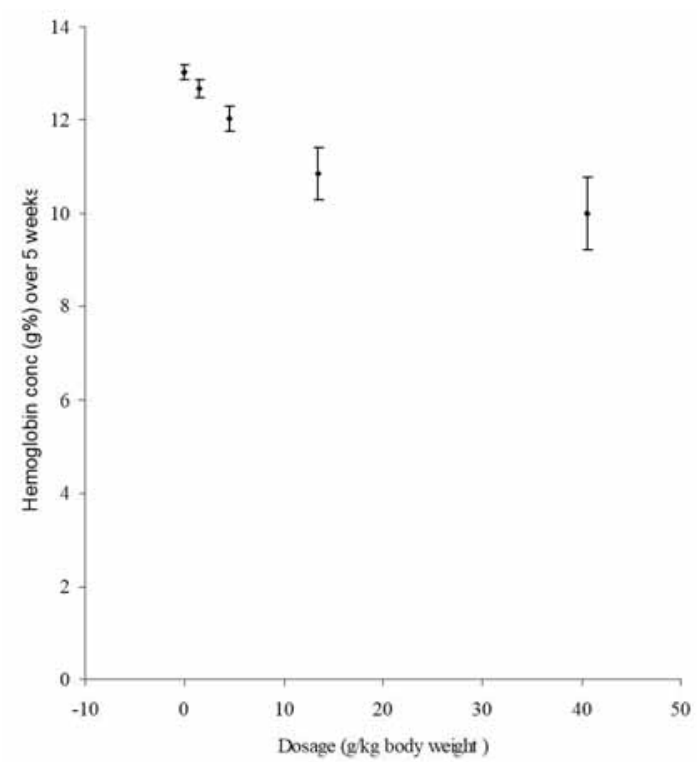

Figure 8b. Effect of khat extract on Haemoglobin ( $\mathrm{Hb})$ concentration in rabbits as a function of khat dose. Khat extract suppressed $\mathrm{Hb}$ concentration in a dose-related manner, with the greatest effect at $40.5 \mathrm{~g} / \mathrm{kg}$ body weight of khat extract $(\mathrm{P}<0.05)$ compared to controls. $\mathrm{n}=25$.

effects of khat extract on testicular morphology using rabbit as experimental model. We, however, report that our study did not consider classification of rabbit seminiferous tubules but rather khat effects on seminiferous epithelium at given stages of development. The results presented here are, therefore, not reflective of all eight cycles of rabbit spermatogenesis (MORTON, 1988) but attempts to explain effects of khat on 


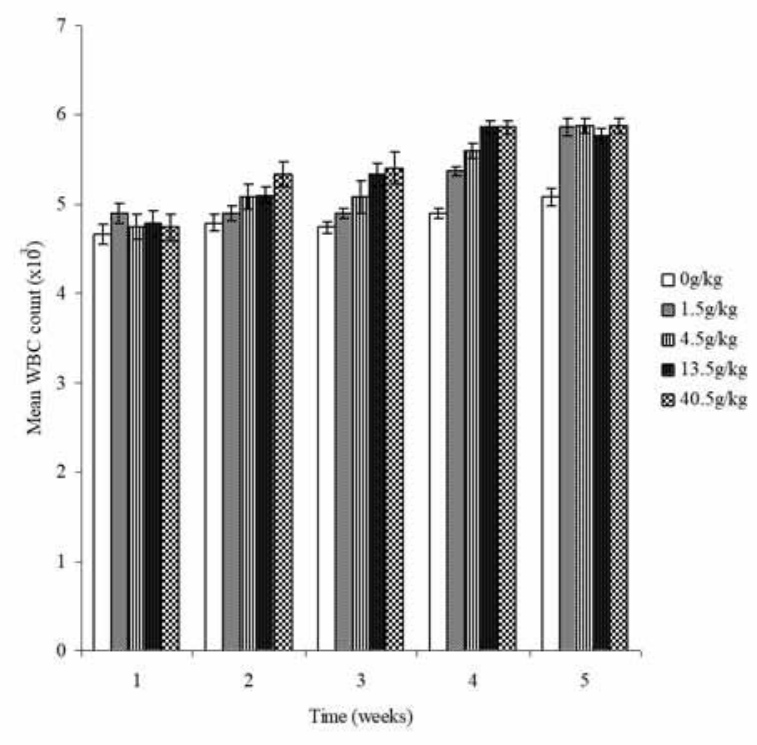

Figure 9a. Mean white blood cell (WBC) count in saline-controls and khat-treated rabbits over a 5 -week experimental period. Khat- treated rabbits showed increased WBC counts which, however, were within the physiological limit. Significant increase in counts $(\mathrm{P}<0.05)$ was seenat week 4 and 5 compared to 1 week. $\mathrm{n}=5$ weeks.

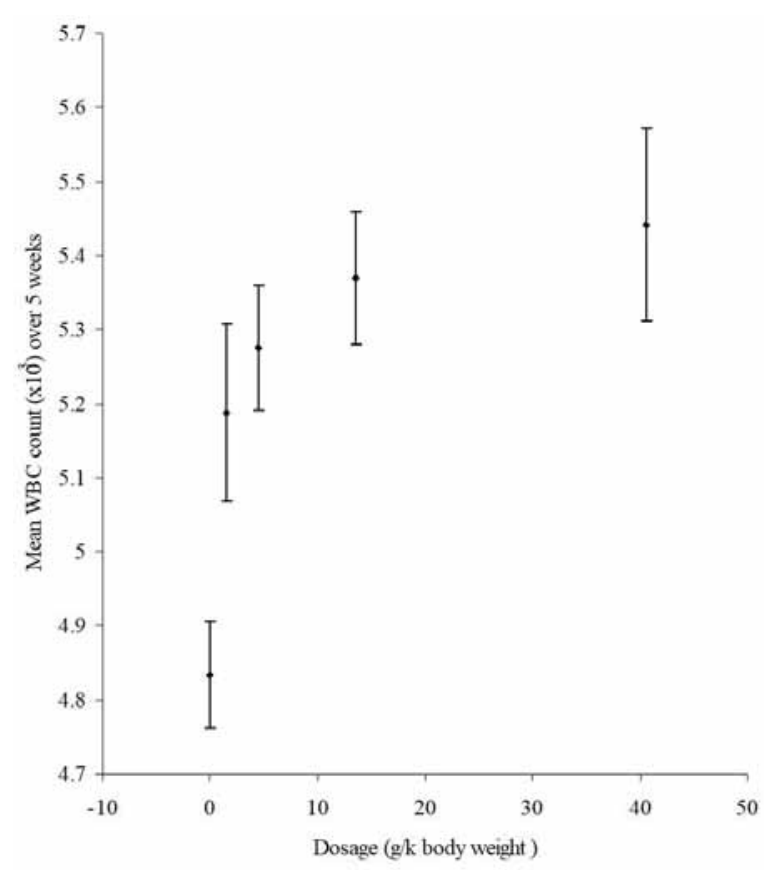

Figure 9b. Mean white blood cell (WBC) count in saline controls and khat-treated rabbits as a function of khat dose. Khat extract increased WBC counts at all doses of khat extract and significant increase $(\mathrm{P}<0.05)$ was seen in rabbits at $13.5 \mathrm{~g} / \mathrm{kg}$ and $40.5 \mathrm{~g} / \mathrm{kg}$ body weight of khat extract compared to controls. $n=25$ rabbits

cellular associations in given testicular sections as a function of dose and duration of exposure. Testicular tissues were fixed in $2.5 \%$ glutaraldehyde and Toluidine staining used to identify nuclei details of cells more clearly as recommended elsewhere (MORTON, 1988). It was important to achieve proper tissue

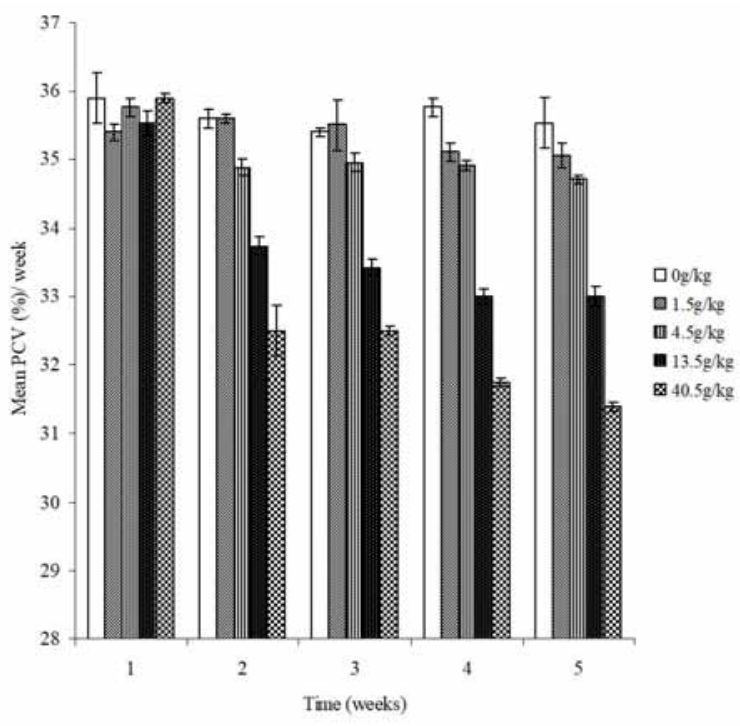

Figure 10a. Mean packed cell volume (PCV) in saline-treated controls and khat-treated rabbits as a function of khat dose. PCV levels declined at all dosages of khat extract. Significantly decline $(\mathrm{P}<0.05)$ was seen in rabbits treated with doses $13.5 \mathrm{~g} / \mathrm{kg}$ and $40.5 \mathrm{~g} / \mathrm{kg}$ body weight of khat extract compared to controls. $\mathrm{n}=25$.

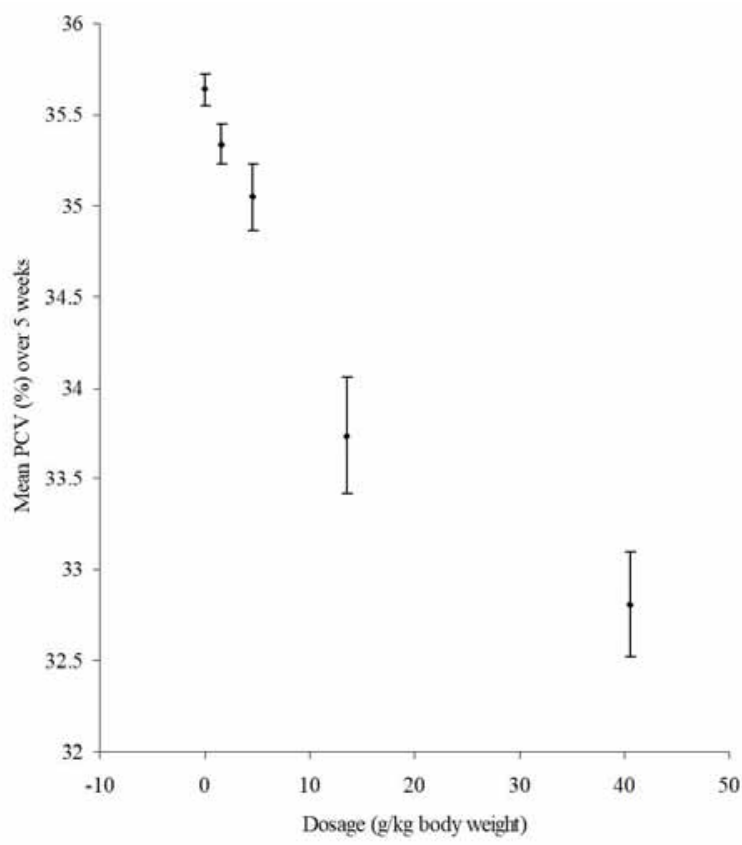

Figure 10b. Packed cell volume (PCV) levels in saline-treated controls and khat-treated rabbits as a function of khat dose. Khat caused a general decrease in PCV in a dose-related manner. Significant reduction $(\mathrm{P}<0.05)$ was seen in rabbits treated with $40.5 \mathrm{~g} / \mathrm{kg}$ body weight of khat extract compared to saline-treated controls. $\mathrm{n}=25$.

fixation as it is critical for detailed histological evaluation of seminiferous epithelium (CREASY, 1997).

Results of the present study showed profound influence of khat on different stages of the spermatogenic cycle. Focal degeneration and vacuolation in spermatogonia and zygotene spermatocytes of treatment groups represent localized toxicological effect from which a proportion of seminiferous 
tubules fail to recover their spermatogenic function. This finding confirms earlier reports on impaired spermatogenesis in mice (TARIQ, QURESHI, AGEEL et al., 1990), rats (ISLAM, TARIQ, AGEEL et al., 1990) and humans (EL-SHOURA, ABDEL AZIZ, ALI et al., 1995) following khat exposure. From the results of this study, it seems apparent that short- and long-term administration of high doses of khat primarily affected immature forms (spermatogonia and zygotene or spermatocytes in their pre-leptotene stage) of germ cells while pachytene spermatocytes, spermatids and spermatozoa appeared generally unaffected. Immature germ cells undergo active mitotic cell division, hence exhibit the greatest dynamic transformation of chromatin. In these stages there is abundance of histones in their nuclei that are highly susceptible to toxic agents while in the maturation stages of sperm formation, chromatin is highly condensed due to the displacement of lysine-rich histones by small arginine and cysteine-rich protamines (CARLSON, 2014) which are unlikely to be affected by these toxic agents. In the present study, therefore, chromatin condensation and subsequent vacuolation in spermatogonia and zygotene spermatocytes all point towards a significant influence of khat on cell division and development. Vacuoles in the seminiferous epithelium are frequently encountered with impaired spermatogenesis as shown by studies in rats treated with heptachlor (WANGO, ONYANGO, ODONGO et al., 1997) and goats treated with ethane dimethanesulphonate (ONYANGO, WANGO, ODUOR-OKELO et al., 2001). The results on interstitial tissue showed, Leydig cells, fibroblasts and endothelial cells associated with blood and lymphatic vessels unaffected at short- and long-term khat extract exposure, similar to findings reported by Mwenda, Owuor, Kyama et al. (2006). The picture is, however, inconclusive since ultra-structural examination of Leydig cells indicating effects on steroidogenic sub-cellular organelles were not considered in the present study.

The blood cell count showed significant reduction of red blood cells, haematocrit and haemoglobin concentration at high doses of khat extract which translated to reduced blood volume. This could have been directly due to khat effects on hemopoietic tissue or secondarily due to impaired steroidogenesis following khat exposure. Previous studies in rabbits (NYONGESA, PATEL, ONYANGO et al., 2008) and rats (MOHAMMED and ENGIDAWORK, 2011) reported a significant reduction in testosterone at high dose of khat extract and following long-term exposure. Testosterone is an erythropoietic hormone that acts directly on polychromatophilic erythroblasts in the bone marrow (GONZALES, TAPIA, GASCO et al., 2011) and is associated with increased haemoglobin at puberty in young men (COVIELLO, KAPLAN, LAKSHMAN et al., 2008). It is also possible that reduced blood volume led to hypoxia due to decreased oxygen supply by the vascular bed. Hypoxic conditions have been shown to cause alterations in sperm parameters in men (VERRATTI, BERARDINELLI, DI GIULIO et al., 2008) and rhesus monkeys (SAXENA, 1995). It is worth noting that these effects on their own, or coupled with elevated body temperature observed with high khat dose exposure in the present study could have affected testicular function in rabbits. Sympathomimetic agents have been shown to induce hyperthermia through production of interleukin- 1 beta (IL-1 $\beta$ ) following neuronal damage (ALBERS and SONSALLA, 1995). Khat contains such sympathomimetic compounds (BALINT and BALINT, 1994). Secretion of luteinizing hormone and follicular stimulating hormone are influenced by cytokines such as IL- $1 \alpha$ and $\beta$, IL- 6 , tumour necrosis factor-alpha (TNF- $\alpha$ ) and interferon-gamma (INF- $\gamma$ ) (SCARBOROUGH, 1990). Tumour necrosis factor-alpha is also expressed as a trans-membrane protein in pachytene spermatocytes, round spermatids and interstitial macrophages (DE, CHEN, PACE et al. 1993) and, together with IL-1 $\beta$ it has been shown to recruit neutrophils in veins of testicular parenchyma (LYSIAK, NGUYEN, KIRBY et al., 2003). High levels of TNF- $\alpha$ have been found in semen samples of infertile men (EGGERT-KRUSE, KIEFER, BECK et al., 2007). From these findings, it is noteworthy to propose hypothetically that khat induced production of TNF- $\alpha$ and IL- $1 \beta$ and enhanced their effects leading to germ cell death. It is unclear, however, whether these cytokines were a cause or a result of the testicular histopathology brought about by khat extract exposure.

The results on clinical observations indicated a significant reduction in body weight gain and food consumption in treatment groups in a dose-related manner. Earlier studies implicated khat consumption with appetite suppressant properties (MURRAY, LE ROUX, EMMANUEL et al., 2008). It has been shown that the arcuate nucleus of the hypothalamus contains Agouti-related protein (AgRP) involved in central appetite regulation (NEARY, GOLDSTONE and BLOOM, 2004). In rodents and primates, arcuate nucleus contains mRNA of neuropeptides involved in feeding and reproduction including neuropeptide $\mathrm{Y}$ (NPY), $\alpha-\mathrm{MSH}, \mathrm{AgRP}$ and galanin (CONE, COWLEY, BUTLER et al., 2001). From the aforementioned, it is possible that presence of khat in the gut stimulated release of neuropeptide Y resulting in observed reduction of feeding in rabbits or interfered with mRNA of neuropeptides in arcuate nucleus involved in regulation of feeding and reproduction. It is also possible that khat interfered with synthesis or release of GALP in the arcuate nucleus or pre-optic area resulting in the observed effects although this is speculative. On the other hand, cathinone has been shown to act on catecholaminergic synapses to increase levels of dopamine, serotonin and noradrenaline in the brain (CALCAGNETTI and SCHECHTER, 1993). Studies showing involvement of 5-HT receptors in appetite regulation in Siberian hamsters treated with fenfluramine observed that fenfluramine exerted a potent hypophagic effect (SCHUHLER, CLARK, JOSEPH et al., 2005 ). Since fenfluramine is known to increase 5-HT release and inhibit its reuptake, these observations demonstrated the involvement of serotonergic system in regulation of food intake. From these observations, it is possible that the observed effects of khat on food intake in rabbits may have been due to their effect on the arcuate nucleus or because of increased levels of 5-HT in the brain. In this study since food and water intake showed positive correlation, both appeared to affect body weight gain significantly. The results confirm earlier findings of Islam, Tariq, Ageel et al. (1990) which reported cathinone, active ingredient of khat, as having reduced body weight gain of rats in a dose-related manner.

Histological structure of various segments of the epididymis did not show any observable lesions following both short- and long-term treatment with khat extract compared to controls. In the caput epididymis, numerous micropinocytotic vesicles, secretory granules and multi-vesicular bodies were observed in the cytoplasm of normal epithelial cells similar to those observed in epididymis of treatment groups. The effect of khat on this measure is in agreement with that in baboons (MWENDA, 
OWUOR, KYAMA et al., 2006) where the epididymides were unaffected. This finding compares favourably with other reports in rabbits (JONES, HAMILTON and FAWCETT, 1979), equines (ARRIGHI, ROMANELLO and DOMENEGHINI, 1993) and goats (ONYANGO, WANGO and WERNER, 2001) where similar dense bodies and micropinocytotic vesicles were reported in normal principal cells of caput epididymis. Histological examination of adenohypophysis showed no adverse effect of khat extract on gonadotropes although the results, in fact, argue for a strong effect of khat on the central aspect of hypothalamo-hypophyseal-gonadal-axis. Immunolocalization of vervet adenohypophysis following sub-chronic cathinone exposure showed enhanced gonadotrophic activity (NYONGESA, ODUMA, AL'ABSI et al., 2015).

\section{Conclusions}

From the aforementioned, this study has provided evidence suggesting that short- and long-term khat extract treatment interferes with testicular function which is compounded by changes in food consumption, body temperature and blood parameters that in turn influence general body performance. While not all stages of spermatogenic cycle of rabbit are reported for this study, the results clearly indicate khat extract effects on spermatogonia and immature spermatocytes in every spermatogenic cycle where these cells occur. The study has demonstrated that khat extract caused overt structural alterations in the seminiferous epithelium of testis of rabbits in a dose-related manner. Together, the results and other available evidence in literature point to the possible reproductive health complications of heavy and long-term khat consumption.

Acknowledgements: This work was funded by a research grant from Deans Committee \# 500-655-635 of the University of Nairobi. The authors wish to thank Messrs Amos Tangai for his technical assistance and Stanley Marete for supply of khat.

\section{References}

ALBERS, DS. and SONSALLA, PK. Methamphetamine-induced hyperthermia and dopaminergic neurotoxicity in mice: Pharmacological profile of protective and non-protective agents. The Journal of Pharmacology and Experimental Therapentics, 1995, vol. 275, n. 3, p. 1104-1114. PMid:8531070.

AL-MAMARY, M., AL-HABORI, M., AL-AGHBARI, AM. and BAKER, MM. Investigation into the toxicological effects of Catha edulis leaves: a short-term study in animals. Phytotherapy Research, 2002, vol. 16, n. 2, p. 127-132. PMid:11933113. http://dx.doi. org/10.1002/ptr.835.

AMANN, RP. Use of animal models for detecting specific alterations in reproduction. Fundamental and Applied Toxicology, 1982, vol. 2, n. 1, p. 13-26. PMid:6764426. http://dx.doi.org/10.1016/ S0272-0590(82)80059-6.

ANDERSON, D., BRINKWORTH, MH., JENKINSON, PC., CLODE, SA., CREASY, DM. and GANGOLLI, SD. Effect of ethylene glycol monomethyl ether on spermatogenesis, dominant lethality and Fl abnormalities in the rat and the mouse after treatment of F0 females. Teratogenesis, Carcinogenesis, and Mutagenesis, 1987, vol. 7, n. 2, p. 141-158. PMid:2885937. http://dx.doi.org/10.1002/ tcm.1770070205.

ARRIGHI, S., ROMANELLO, MG. and DOMENEGHINI, C. Ultrastructure of epididymal epithelium of Equns caballus. Annals of Anatomy, 1993, vol. 175, n. 1, p. 1-9. PMid:8465967. http:// dx.doi.org/10.1016/S0940-9602(11)80229-3.

BALINT, GA. and BALINT, EE. On the medico-social aspects of khat (Catha edulis) chewing habit. Human Psychopharmacology, 1994, vol. 9, n. 2, p. 125-128. http://dx.doi.org/10.1002/hup.470090206.

CALCAGNETTI, DJ. and SCHECHTER, MD. Place preference for the psychostimulant-cathinone is blocked by pretreatment with a dopamine release inhibitor. Progress in Neuro-Psychopharmacology o Biological Psychiatry, 1993, vol. 17, n. 4, p. 637-649. PMid:8103235. http://dx.doi.org/10.1016/0278-5846(93)90011-G.

CARLSON, BM. Human embryology and developmental biology. 5th ed. Philadelphia: Saunders, 2014.

CARRIER, N. Bundles of choice: Variety and the creation and manipulation of Kenyan khat's value. Ethnos, 2006, vol. 71, n. 3, p. 415-437. http://dx.doi.org/10.1080/00141840600902737.

CONE, RD., COWLEY, MA., BUTLER, AA., FAN, W., MARKS, DL. and LOW, MJ. The arcuate nucleus as a conduit for diverse signals relevant to energy homeostasis. International Journal of Obesity and Related Metabolic Disorders, 2001, vol. 25, n. 5, Suppl 5, p. S63-S67. PMid:11840218. http://dx.doi.org/10.1038/sj.ijo.0801913.

COVIELLO, AD., KAPLAN, B., LAKSHMAN, KM., CHEN, T., SINGH, AB. and BHASIN, S. Effects of graded doses of testosterone on erythropoiesis in healthy young and older men. The Journal of Clinical Endocrinology and Metabolism, 2008, vol. 93, n. 3, p. 914919. PMid:18160461. http://dx.doi.org/10.1210/jc.2007-1692.

COX, G. and RAMPES, H. Adverse effects of khat: a review. Advances in Psychiatric Treatment, 2003, vol. 9, n. 6, p. 456-463. http:// dx.doi.org/10.1192/apt.9.6.456.

CREASY, DM. Evaluation of testicular toxicity in safety evaluation studies: the appropriate use of spermatogenic staging. Toxicologic Pathology, 1997, vol. 25, n. 2, p. 119-131. PMid:9125770. http:// dx.doi.org/10.1177/019262339702500201.

DE, SK., CHEN, HL., PACE, JL., HUNT, JS., TERRANOVA, PF. and ENDERS, GC. Expression of tumor necrosis factor- $\alpha$ in mouse spermatogenic cells. Endocrinology, 1993, vol. 133, n. 1, p. 389-396. PMid:8319585. http://dx.doi.org/10.1210/endo.133.1.8319585.

EGGERT-KRUSE, W., KIEFER, I., BECK, C., DEMIRAKCA, T. and STROWITZKI, T. Role for tumor necrosis factor alpha (TNF- $\alpha$ ) and interleukin 1- beta (IL-1 $\beta$ ) determination in seminal plasma during infertility investigation. Fertility and Sterility, 2007, vol. 87, n. 4, p. 810-823. PMid:17430733. http://dx.doi.org/10.1016/j. fertnstert.2006.08.103.

EL-SHOURA, SM., ABDEL AZIZ, M., ALI, ME., EL-SAID, MM., ALI, KZ., KEMEIR, MA., RAOOF, AM., ALLAM, M. and ELMALIK, EM. Deleterious effects of khat addiction on semen parameters and sperm ultrastructure. Human Reproduction, 1995, vol. 10, n. 9, p. 2295-2300. PMid:8530655. http://dx.doi.org/10.1093/ oxfordjournals.humrep.al36288.

ENVIRONMENTAL PROTECTION AGENCY - EPA. Health effects test guidelines: combined repeated dose toxicity study with the reproduction/developmental toxicity screening test. Washington: United States Environmental Protection Agency, 2000. 712-C-00-368.

FEYISSA, AM. and KELLY, JP. A review of the neuropharmacological properties of khat. Progress in Neuropharmacology and Biological Psychiatry, 2008, vol. 32, n. 5, p. 1147-1166. PMid:18561890.

GONZALES, GF., TAPIA, V., GASCO, M., RUBIO, J. and GONZALESCASTAÑEDA, C. High serum zinc and serum testosterone levels were associated with excessive erythrocytosis in men at high altitudes. Endocrine, 2011, vol. 40, n. 3, p. 472-480. PMid:21553128. http:// dx.doi.org/10.1007/s12020-011-9482-1.

ISLAM, MW., TARIQ, M., AGEEL, AM., EL-FERALY, FS., ALMESHAL, IA. and ASHRAF, I. An evaluation of the male reproductive 
toxicity of cathinone. Toxicology, 1990, vol. 60, n. 3, p. 223-234. http://dx.doi.org/10.1016/0300-483X(90)90145-7.

JONES, R., HAMILTON, DW. and FAWCETT, DW. Morphology of epithelium of the extra-testicular rete testis, ductuli efferentes and ductus epididymis of the adult male rabbit. The American Journal of Anatomy, 1979, vol. 156, n. 3, p. 373-400. PMid:532791. http:// dx.doi.org/10.1002/aja.1001560307.

KLEIN, A., METAAL, P. and JELSMA, M. Chewing over khat probibition: the globalization of control and regulation of ancient stimulant. Amsterdam: Transnational Institute, 2012. Series on Legislative Reform of Drug Policies, vol. 17.

LYSIAK, JJ., NGUYEN, QA., KIRBY, JL. and TURNER, TT. Ischemia-reperfusion of the murine testis stimulates the expression of pro-inflammatory cytokines and activation of c-jun $\mathrm{N}$-terminal kinase in a pathway to E-selection expression. Biology of Reproduction, 2003, vol. 69, n. 1, p. 202-210. PMid:12620934. http://dx.doi. org/10.1095/biolreprod.102.013318.

MOHAMMED, A. and ENGIDAWORK, E. Reproductive parameters are differentially altered following subchronic administration of Catha edulis Forsk (Khat) extract and cathinone in male rats. Journal of Ethnopharmacology, 2011, vol. 134, n. 3, p. 977-983. PMid:21335082. http://dx.doi.org/10.1016/j.jep.2011.02.006.

MORTON, D. The use of rabbits in male reproductive toxicology. Environmental Health Perspectives, 1988, vol. 77, p. 5-9. PMid:3383822. http://dx.doi.org/10.1289/ehp.88775.

MURRAY, CD., LE ROUX, CW., EMMANUEL, AV., HALKET, JM., PRYBOROWSKA, AM., KAMM, MA. and MURRAY-LYON, IM. The effect of khat (Catha edulis) as an appetite suppressant is independent of ghrelin and PYY secretion. Appetite, 2008, vol. 51, n. 3, p. 747-750. PMid:18656509. http://dx.doi.org/10.1016/j. appet.2008.06.012.

MWENDA, JM., OWUOR, RA., KYAMA, CM., WANGO, EO., M'ARIMI, M. and LANGAT, DK. Khat (Catha edulis) up-regulates testosterone and decreases prolactin and cortisol levels in the baboon. Journal of Ethnopharmacology, 2006, vol. 103, n. 3, p. 379-384. PMid:16198525. http://dx.doi.org/10.1016/j.jep.2005.08.016.

NEARY, NM., GOLDSTONE, AP. and BLOOM, SR. Appetite regulation: from the gut to the hypothalamus. Horumon To Rinsho, 2004, vol. 60, n. 2, p. 153-160. PMid:14725674.

NYONGESA, AW. and ONYANGO, DW. Khat (Catha edulis Forsk): a boon or bane to humanity. In AWAAD, A., SINGH, VK. and GOVIL, JN. Recent progress in medicinal plants. Texas: Studium Press LLC, 2010. p. 173-193. vol. 28. Available from: <studiumpress.in/indetail. asp?id=86>. Access in: 17 Jan. 2017.

NYONGESA, AW., ODUMA, JA., AL'ABSI, M. and CHIRWA, S. Immunohistochemical localization of anterior pituitary cell types of vervet monkeys (Chlorocebus aethiops) following sub-chronic cathinone exposure. Journal of Ethnopharmacology, 2015, vol. 174, p. 168-177. PMid:26277490. http://dx.doi.org/10.1016/j.jep.2015.08.007.

NYONGESA, AW., PATEL, NB., ONYANGO, DW., ODONGO, HO. and WANGO, EO. Khat (Catha edulis) lowers plasma luteinizing hormone $(\mathrm{LH})$ and testosterone secretion, but increases cortisol levels in male rabbits. Journal of Ethnopharmacology, 2008, vol. 116, n. 2, p. 245-250. PMid:18180121. http://dx.doi.org/10.1016/j. jep.2007.11.022.

ONYANGO, DW., WANGO, EO., ODUOR-OKELO, D. and WERNER, G. Early testicular response to intraperitoneal administration of ethane dimethanesulphonate (EDS) in the goat (Capra hircus).
Journal of Submicroscroscopic Cytology and Pathology, 2001, vol. 33, n. 1-2, p. 117-124. PMid:11686392.

ONYANGO, DW., WANGO, EO. and WERNER, G. Epididymal epithelial cell involution following a single intraperitoneal administration of ethane dimethanesulphonate in the goat (Capra hircus). Toxicology and Applied Pharmacology, 2001, vol. 175, n. 1, p. 19-27. PMid:11509023. http://dx.doi.org/10.1006/taap.2001.9225.

QURESHI, S., TARIQ, M. and PAMAR, NS. Cytological effects of khat (Catha edulis) in somatic and male germ cells of mice. Drug and Chemical Toxicology, 1988, vol. 11, n. 2, p. 151-165. PMid:2900128. http://dx.doi.org/10.3109/01480548808998219.

SAXENA, DK. Effects of hypoxia by intermittent altitude exposure on semen characteristics and testicular morphology of male rhesus monkeys. International Journal of Biotechnology, 1995, vol. 38, n. 3, p. 137-140. PMid:7744528.

SCARBOROUGH, DE. Cytokine modulation of pituitary hormone secretion. Annals of the New York Academy of Sciences, 1990, vol. 594, n. 1, p. 169-187. PMid:2143056. http://dx.doi. org/10.1111/j.1749-6632.1990.tb40477.x.

SCHUHLER, S., CLARK, A., JOSEPH, W., PATEL, A., LEHNEN, K., STRATFORD, E., HORAN, TL., FONE, KC. and EBLING, FJ. Involvement of 5-HT receptors in the regulation of food intake in Siberian hamsters. Journal of Neuroendocrinology, 2005, vol. 17, n. 5, p. 276-285. PMid:15869562. http://dx.doi.org/10.1111/j.13652826.2005.01303.x.

SWIERSTRA, EE. and FOOTE, RH. Cytology and kinetics of spermatogenesis in the rabbit. Journal of Reproduction and Fertility, 1963, vol. 5, n. 3, p. 309-322, NP. PMid:13979709. http://dx.doi. org/10.1530/jrf.0.0050309.

TAKAYAMA, S., AKAIKE, M., KAWASHIMA, K., TAKAHASHI, M. and KUROKAWA, Y. A collaborative study in Japan on optimal treatment period of parameters for detection of male fertility disorders induced by drugs in rats. Journal of The American College of Toxicologists, 1995, vol. 14, n. 4, p. 266-292. http://dx.doi. org/10.3109/10915819509008702.

TARIQ, M., QURESHI, S., AGEEL, AM. and AL-MESHAL, IA. The induction of dominant lethal mutations upon chronic administration of qat (Catha edulis) in albino mice. Toxicology Letters, 1990, vol. 50, n. 2-3, p. 349-353. PMid:2309252. http://dx.doi.org/10.1016/03784274(90)90028-K.

VERRATTI, V., BERARDINELLI, F., DI GIULIO, C., BOSCO, G., CACCHIO, M., PELliCCIOTTA, M., NICOLAI, M., MARTINOTTI, S. and TENAGLIA, R. Evidence that chronic hypoxia causes reversible impairment on male fertility. Asian Journal of Andrology, 2008, vol. 10, n. 4, p. 602-606. PMid:18097511. http:// dx.doi.org/10.1111/j.1745-7262.2008.00346.x.

WANGO, EO., ONYANGO, DW., ODONGO, H., OKINDO, E. and MUGWERU, J. In vitro production of testosterone and plasma levels of luteinizing hormone, testosterone and cortisol in male rats treated with heptachlor. Comparative Biochemistry and Physiology Part C, 1997, vol. 118, n. 3, p. 381-386. PMid:9467889.

ZELGER, J., SCHORNO, H. and CARLIN, E. Behavioural effects of cathinone: an amphetamine obtained from Catha edulis: comparisons with amphetamine, norpseudoephedrine, apomorphine and nomifensine. Bulletin on Narcotics, 1980, vol. 32, n. 3, p. 67-81. PMid:6911034.

Received January 10, 2017 Accepted August 18, 2017 